\title{
Assimilation of Ammonia by Bacteroides amylophilus in Chemostat Cultures
}

\author{
By H. F. JENKINSON, * P. J. BUTTERY AND D. LEWIS \\ Department of Applied Biochemistry and Nutrition, University of Nottingham, School of \\ Agriculture, Sutton Bonington, Leicestershire LE12 5RD
}

(Received 3 January 1979)

\begin{abstract}
The size of the amino acid pool in Bacteroides amylophilus, a rumen bacterium, was limited by the availability of ammonia in the growth medium. Alanine was the major pool constituent irrespective of the growth-limiting nutrient. In steady-state ammonia-limited chemostat cultures, glutamine synthetase (GS) activity was tenfold higher and glutamate dehydrogenase (GDH) activity up to fivefold lower than in maltose-limited cultures. No glutamate synthase (GOGAT) activity was demonstrated. When excess ammonia was pulsed into an ammonia-limited chemostat culture, the glutamine pool expanded rapidly and GS was inactivated. This was consistent with the observation that, in a number of bacteria, GS functions to assimilate ammonia when the prevailing concentration is low. However, GDH was always very active in extracts of $B$. amylophilus and its Michaelis constant for ammonia was relatively low (1 to $2 \mathrm{~mm}$ ). This suggested that GDH could continue to function biosynthetically when GS was derepressed.
\end{abstract}

\section{INTRODUCTION}

Although there is considerable interest in the mechanisms of protein degradation and synthesis in the rumen and especially in the use of non-protein nitrogen as a source of nitrogen for ruminants (Buttery \& Annison, 1973), there is surprisingly little information on the mechanisms of amino acid biosynthesis by pure cultures of rumen bacteria. The peptides, amino acids and ammonia which arise as end-products of dietary protein breakdown act as nitrogen sources for the rumen microbes (see, for example, Lewis \& Swan, 1971). However, it is generally accepted that ammonia is quantitatively the most important nitrogenous nutrient for the rumen bacteria and for many species it is essential for growth (Allison, 1970).

The various routes by which ammonia may be assimilated by bacteria have been discussed by Brown et al. (1974). It is apparent that neither aspartase nor alanine dehydrogenase generally has a biosynthetic function and also that glutamate dehydrogenase may not function effectively except when the environmental concentration of ammonia is relatively high (Meers et al., 1970). Under conditions of low ammonia availability, the two enzymes glutamine synthetase and glutamate synthase together provide a route for the incorporation of ammonia in a wide variety of bacteria (Meers et al., 1970; Brown \& Stanley, 1972; Dainty, 1972; Tyler, 1978).

Glutamate dehydrogenase activity has been detected in nine species of rumen bacteria which were considered representative of about $40 \%$ of the rumen microbial population (Joyner \& Baldwin, 1966). It was assumed that a pathway involving this enzyme was the major route by which ammonia was fixed by the rumen bacterial population (Allison, 1970).

* Present address: Microbiology Unit, Department of Biochemistry, University of Oxford, Oxford OX1 3QU. 
Glutamine synthetase activity was detected in extracts of mixed rumen bacteria (Chalupa et al., 1970) and this enzyme might also operate to assimilate ammonia to provide glutamine which serves as the nitrogen donor in the biosynthesis of many diverse metabolites (Shapiro \& Stadtman, 1970a).

Bacteroides amylophilus is an obligately anaerobic, Gram-negative rod which may constitute about $10 \%$ of the rumen bacterial population in animals fed certain diets (Hungate, 1966). Ammonia is essential for growth although there is some evidence for limited amino acid uptake (Hullah \& Blackburn, 1971). The work reported in this paper examines some of the physiological aspects of the assimilation of ammonia by this organism. When suspended in a medium devoid of ammonia, the cells became swollen and leaked nitrogencontaining compounds but remained intact (Henderson et al., 1969). Under ammonia limitation in a chemostat $\left(D<0.08 \mathrm{~h}^{-1}\right)$, a considerable amount of cell debris was microscopically visible in suspension. Nitrogen limitation was evidently severe in this organism and the possibility that this might be reflected by the mode of ammonia incorporation or regulation of nitrogen metabolism was investigated.

\section{METHODS}

Abbreviations. GDH, Glutamate dehydrogenase; GOGAT, glutamate synthase; GS, glutamine synthetase; $\gamma \mathrm{GT}, \gamma$-glutamyltransferase; MDH, malste dehydrogenase; $\mathrm{ADH}$, alanine dehydrogenase; GOT, glutamate-oxaloacetate transaminase; GPT, glutamate-pyruvate transaminase.

Organism. Bacteroides amylophilus strain WP91, kindly supplied by Dr P. N. Hobson, Rowett Research Institute, Bucksburn, Aberdeen, was maintained at $4{ }^{\circ} \mathrm{C}$ in MT agar [containing maltose $\left(3 \mathrm{~g} \mathrm{l}^{-1}\right)$, Tryptone $\left(3 \mathrm{~g} \mathrm{l}^{-1}\right)$ and Ionagar $\left.(1 \cdot 5 \%, \mathrm{w} / \mathrm{v})\right]$ and was subcultured every 3 weeks. Lyophilized suspensions, prepared according to Blackburn (1968), were reconstituted at intervals.

Culture media. Bacteroides amylophilus was grown in a basal medium which, unless otherwise stated, contained ( $\mathrm{gl} l^{-1}$ in distilled water): $\mathrm{K}_{2} \mathrm{HPO}_{4}, 0.45 ; \mathrm{KH}_{2} \mathrm{PO}_{4}, 0.45 ; \mathrm{NaCl}, 0.90 ;\left(\mathrm{NH}_{4}\right)_{2} \mathrm{SO}_{4}, 0.90 ; \mathrm{MgSO}_{4} .7 \mathrm{H}_{2} \mathrm{O}$, $0.09 ; \mathrm{CaCl}_{2}, 0.09$; resazurin, $0.001 ; \mathrm{NaHCO}_{3}, 5.0 ; \mathrm{L}$-cysteine hydrochloride, 0.08 (Blackburn, 1965; Hobson \& Summers, 1967). The mineral ingredients were stored as concentrated solutions at $4{ }^{\circ} \mathrm{C}$. The phosphate components were added as a heat-sterilized solution $\left(121^{\circ} \mathrm{C}, 15 \mathrm{~min}\right)$ to the autoclaved bulk medium. Resazurin, bicarbonate and cysteine (reducing agent) solutions were prepared on the day of use. For continuous cultures, maltose limitation was obtained with $3 \mathrm{~g} \mathrm{l}^{-1}$ in basal medium, and ammonia limitation with $\left(\mathrm{NH}_{4}\right)_{2} \mathrm{SO}_{4}$ at $0.143 \mathrm{~g} \mathrm{l}^{-1}$ and maltose at $4.5 \mathrm{~g} \mathrm{l}^{-1}$. The redox potential $\left(E_{\mathrm{h}}\right)$ of reduced medium was about $-250 \mathrm{mV}$ as measured with a calomel electrode.

Anaerobic methods. Liquid media were prepared according to Latham \& Sharpe (1971). Broth cultures were transferred with sterile plastic disposable syringes fitted with size 21 gauge, $4 \mathrm{~cm}$ Luer hypodermic needles by inoculating through the rubber stoppers sealing the growth vessels. Cultures were grown in $100 \mathrm{ml}$ medium in $150 \mathrm{ml}$ medical flat bottles fitted with black butyl rubber bungs (A. R. Horwell, Grangeway, Kilburn High Rd, London). For continuous cultures, medium was autoclaved at $121^{\circ} \mathrm{C}$ for $1 \mathrm{~h}$ and equilibrated overnight under $\mathrm{CO}_{2}$ prior to the addition of sterile solutions of phosphate buffer, maltose, bicarbonate and reducing agent (Hobson, 1965). All cultures were incubated at $39^{\circ} \mathrm{C}$ under $\mathrm{CO}_{2}$. The initial pH was 6.6 to $6 \cdot 8$.

Contintous cultures. Cultures (2 l) were grown in a stirred fermenter (FL103; Biotec, Stockholm, Sweden) with the $\mathrm{pH}$ controlled at 6.2 by automatic addition of $10 \%(\mathrm{w} / \mathrm{v}) \mathrm{NaOH}$ and the temperature held at $39{ }^{\circ} \mathrm{C}$. The organisms were grown to late-exponential phase as a batch culture in the fermenter prior to commencing medium input. A positive pressure was maintained in the vessel by sparging with sterile $\mathrm{O}_{2}$-free $\mathrm{CO}_{2}$ (50 to $\left.100 \mathrm{ml} \mathrm{min}{ }^{-1}\right)$. This, in combination with a slow impeller speed ( $80 \mathrm{rev}$. min ${ }^{-1}$ ), effected complete mixing. Sterile feed medium was pumped from a 201 storage reservoir by a Micropump Series II (Metering Pumps, Ealing, London) fitted with either a size 4 or size 2 pumphead; the latter was used for input rates of less than $300 \mathrm{ml} \mathrm{h}^{-1}$. The pumphead was cooled with a cold water jacket during operation to avoid the formation of $\mathrm{CO}_{2}$ bubbles in the medium lines. About five volume changes of medium were passed through the cultures to establish steady states before the dilution rate or medium mixture was changed.

Culture analysis. Bacterial growth was monitored turbidimetrically at $660 \mathrm{~nm}$ with a Pye Unicam SP600 Series II spectrophotometer. Dry weight was determined by centrifuging a measured volume (about $40 \mathrm{ml}$ ) of culture $\left(15000 \mathrm{~g}, 15 \mathrm{~min}, 4{ }^{\circ} \mathrm{C}\right)$, resuspending the pellet in about $30 \mathrm{ml} 0 \cdot 15 \mathrm{M}-\mathrm{NaCl}$ in $0.02 \mathrm{M}-\mathrm{KH}_{2} \mathrm{PO}_{4} /$ $\mathrm{K}_{2} \mathrm{HPO}_{4}$ buffer (pH 6.4) and recentrifuging. After a final wash with $0.015 \mathrm{M}-\mathrm{NaCl}$, the bacteria were dried to constant weight at $85^{\circ} \mathrm{C}$. 
Maltose in cell-free culture supernatants was determined by the method of Dubois et al. (1956) using $5 \%(w / v)$ phenol. Ammonia was estimated by micro-diffusion (Conway, 1962).

Amino acid pools. To assess the intracellular free amino acid pool content and composition of B. amylophilus, bacteria were extracted with $\mathrm{HClO}_{4}$ as described by Tempest et al. (1970). Similar results were obtained when bacteria were extracted with boiling water for $10 \mathrm{~min}$ (Dawson, 1965). Basic amino acids were analysed with a Locarte Mk IV amino acid analyser; acidic and neutral amino acids were analysed with an EEL model 294 analyser converted to Locarte specification (Atkin \& Ferdinand, 1970). The amino acids were assayed with ninhydrin and quantified by comparing the peak areas from the chart recordings with those of internal standards. The total amino acid pool was assessed by summing the concentrations of those amino acids whose concentration was greater than or equal to $0.1 \mathrm{~mm}$. To determine the amino acid content of culture supernatants, samples were deproteinized with $0.25 \mathrm{M}-\mathrm{HClO}_{4}$, centrifuged, neutralized and applied to the columns of the analysers.

When the pools were extracted from a number of samples simultaneously, bacteria were harvested by membrane filtration (Millipore, $0.45 \mu \mathrm{m}$ pore size) and the filters were suspended in $4 \mathrm{ml}$ ice-cold $0.25 \mathrm{M}$ $\mathrm{HClO}_{4}$. Similar results were obtained for the content and composition of the pools extracted from bacteria harvested by centrifugation or by filtration.

Extraction of enzymes. Culture samples (10 to $20 \mathrm{mg}$ dry wt cells) were collected in an ice-cold receiver, centrifuged $\left(15000 \mathrm{~g}, 5 \mathrm{~min}, 2^{\circ} \mathrm{C}\right)$ and then the pellet was dispersed in about $30 \mathrm{ml} 50 \mathrm{~mm}$-Tris/HCl buffer (pH 7.6) containing $10 \mathrm{~mm}$-2-mercaptoethanol (Meers et al., 1970). After recentrifuging, the bacteria were resuspended to approximately 2 to $5 \mathrm{mg}$ dry $\mathrm{wt} \mathrm{ml}^{-1}$ in similar buffer. They were disrupted either (i) in a Hughes pressure cell (Hughes, 1951), the crushed material, after thawing, being centrifuged at $20000 \mathrm{~g}$ for $20 \mathrm{~min}$ at $4{ }^{\circ} \mathrm{C}$ or (ii) with an MSE ultrasonic disintegrator $(1 \mathrm{~cm}$ diam. probe, $60 \mathrm{~W}, 5 \mathrm{~min})$, a crude extract being obtained as before. The latter method gave slightly lower activities than the former and was only used when a number of samples required disruption consecutively. The enzyme activities in the crude extracts were measured as soon as possible after preparation. Protein concentrations were determined by the method of Lowry.

Determination of enzyme activity. Glutamate dehydrogenase [GDH; EC 1.4.1.4; L-glutamate:NADP+ oxidoreductase] activity in crude extracts was measured spectrophotometrically from the rate of NADPH oxidation at $340 \mathrm{~nm}$. The assay mixture $(3 \mathrm{ml})$ was similar to that of Meers et al. $(1970)$ except that the buffer was $50 \mathrm{~mm}$-Tris $/ \mathrm{HCl}$, pH 8.0. GDH activity was also measured by the rate of glutamate oxidation as described by Chalupa et al. (1970). Glutamate synthase [GOGAT; EC 1.4.1.13; L-glutamate: NADP+ oxidoreductase (transaminating)] activity was measured spectrophotometrically from the rate of NAD(P)H oxidation at $340 \mathrm{~nm}$; the components of the assay mixture $(3 \mathrm{ml})$ were similar to those of Cole et al. (1974) except that the buffer was $50 \mathrm{~mm}-\mathrm{Tris} / \mathrm{HCl}, \mathrm{pH} 8 \cdot 0$. GDH and GOGAT activities were measured at $22^{\circ} \mathrm{C}$.

Glutamine synthetase [GS; EC 6.3.1.2; L-glutamate:ammonia ligase (ADP-forming)] was measured by its synthetase and transferase activities. Synthetase activity was determined by the method described by Rowe et al. (1970). The assay mixture $(2 \mathrm{ml})$ for the measurement of $\gamma$-glutamyl transferase $(\gamma \mathrm{GT})$ activity contained (mM): imidazole/ $\mathrm{HCl}, \mathrm{pH} 7 \cdot 0,50$; sodium arsenate, 40; L-glutamine, 40; hydroxylammonium chloride, 12; $\mathrm{MnCl}_{2}, 10$; ADP (sodium salt), 8 (Woolfolk et al., 1966). After $30 \mathrm{~min}$ at $37^{\circ} \mathrm{C}$, the reaction was stopped by adding $2 \mathrm{ml} 24 \%(\mathrm{w} / \mathrm{v})$ trichloroacetic acid $/ 6 \mathrm{M}-\mathrm{HCl} / 10 \%$ (w/v) $\mathrm{FeCl}_{3} \cdot 6 \mathrm{H}_{2} \mathrm{O}$ (in $0.02 \mathrm{M}-$ $\mathrm{HCl}) / \mathrm{H}_{2} \mathrm{O}(1: 1: 1: 4 \cdot 5$, by vol.). The absorbance at $510 \mathrm{~nm}$ was referred to that of a standard $\mathrm{L}$-glutamic acid $\gamma$-monohydroxamate solution with $\mathrm{FeCl}_{3}$ reagent.

Malate dehydrogenase [MDH; EC 1.1.1.37; L-malate: NAD $^{+}$oxidoreductase] activity was estimated as described by Reeves et al. (1971) at $22^{\circ} \mathrm{C}$ and pH 7.4. Alanine dehydrogenase [ADH; EC 1.4.1.1; L-alanine: $\mathrm{NAD}^{+}$oxidoreductase] activity was determined as described by Griffith \& Carlsson (1974). Glutamate-oxaloacetate transaminase [GOT; EC 2.6.1.1; L-aspartate:2-oxoglutarate aminotransferase] and glutamate-pyruvate transaminase [GPT; EC 2.6.1.2; L-alanine:2-oxoglutarate aminotransferase] activities were measured by the 2,4-dinitrophenylhydrazine reaction (Sigma Technical Bulletin no. 505, 1977).

The enzyme activities were determined as far as possible under near optimal conditions. Reaction velocities were proportional to the enzyme concentration and initial rates were determined where appropriate. Estimates were corrected for endogenous rates measured in the absence of substrates. NAD(P)H oxidase activity in cell extracts was, however, usually negligible. Specific enzyme activity was expressed as nmol product formed $\mathrm{min}^{-1}$ (mg protein) ${ }^{-1}$, assuming a value of $\epsilon_{340}$ for NADPH and NADH of $62001 \mathrm{~mol}^{-1} \mathrm{~cm}^{-1}$ and a value of $\epsilon_{510}$ for L-glutamic acid $\gamma$-monohydroxamate of $5201 \mathrm{~mol}^{-1} \mathrm{~cm}^{-1}$.

Chemicals. Ionagar and Tryptone were from Oxoid and buffers, substrates and nucleotides were from Sigma, except for the sodium salts of ADP and ATP which were obtained from Boehringer. Other materials were of analytical reagent grade quality. 
Table 1. Effect of dilution rate and nature of nutrient limitation on the intracellular free amino acid pool content and composition during growth of B. amylophilus in chemostat cultures

\begin{tabular}{|c|c|c|c|c|c|c|}
\hline \multirow[b]{2}{*}{ Dilution rate $\left(\mathrm{h}^{-1}\right)$} & \multicolumn{3}{|c|}{ Maltose limitation } & \multicolumn{3}{|c|}{ Ammonia limitation } \\
\hline & $\ldots 0.08$ & $0 \cdot 15$ & 0.39 & $0 \cdot 04$ & 0.09 & $0 \cdot 15$ \\
\hline Aspartate & $0 \cdot 3$ & $0 \cdot 4$ & $0 \cdot 5$ & ND & ND & $0 \cdot 2$ \\
\hline Threonine & $0 \cdot 3$ & $0 \cdot 2$ & $0 \cdot 3$ & ND & ND & $0 \cdot 7$ \\
\hline Serine & $0 \cdot 2$ & $0 \cdot 5$ & 0.5 & ND & ND & 0.5 \\
\hline Glutamate & $2 \cdot 3$ & 1.9 & $1 \cdot 7$ & 0.6 & $1 \cdot 0$ & $2 \cdot 1$ \\
\hline Glutamine & $0 \cdot 4$ & $0 \cdot 2$ & $0 \cdot 5$ & ND & ND & $0 \cdot 1$ \\
\hline Proline & ND & ND & ND & ND & ND & ND \\
\hline Glycine & ND & $0 \cdot 6$ & $0 \cdot 8$ & ND & ND & $0 \cdot 4$ \\
\hline Alanine & $4 \cdot 6$ & $9 \cdot 0$ & $7 \cdot 3$ & $0 \cdot 9$ & $3 \cdot 4$ & $5 \cdot 0$ \\
\hline Valine & $2 \cdot 3$ & $1 \cdot 9$ & $2 \cdot 4$ & $0 \cdot 8$ & $0 \cdot 3$ & $0 \cdot 4$ \\
\hline Methionine & ND & ND & $0 \cdot 1$ & ND & ND & ND \\
\hline Isoleucine & ND & ND & $0 \cdot 2$ & ND & ND & $0 \cdot 3$ \\
\hline Leucine & ND & ND & $0 \cdot 2$ & ND & ND & ND \\
\hline Tyrosine & ND & ND & $0 \cdot 1$ & ND & ND & ND \\
\hline Lysine & $2 \cdot 0$ & $2 \cdot 8$ & $3 \cdot 0$ & $0 \cdot 3$ & $1 \cdot 2$ & $2 \cdot 4$ \\
\hline Histidine & ND & ND & ND & ND & ND & ND \\
\hline Arginine & ND & ND & ND & ND & ND & ND \\
\hline Total pool & $12 \cdot 4$ & $17 \cdot 5$ & $17 \cdot 6$ & $2 \cdot 6$ & $5 \cdot 9$ & $12 \cdot 1$ \\
\hline $\begin{array}{l}\text { Glutamate } \\
\text { portion }(\%)\end{array}$ & $18 \cdot 5$ & $10 \cdot 8$ & $9 \cdot 6$ & $23 \cdot 0$ & $16 \cdot 9$ & $17 \cdot 3$ \\
\hline Glutamine & & & & & & \\
\hline portion (\%) & $3 \cdot 2$ & $1 \cdot 8$ & $2 \cdot 8$ & 一 & 一 & $0 \cdot 8$ \\
\hline $\begin{array}{l}\text { Alanine } \\
\text { portion }(\%)\end{array}$ & $37 \cdot 1$ & $51 \cdot 4$ & $41 \cdot 5$ & $34 \cdot 6$ & $57 \cdot 6$ & $41 \cdot 3$ \\
\hline $\begin{array}{l}\text { Extracellular } \\
\text { ammonia (mM) }\end{array}$ & $11 \cdot 5$ & $10 \cdot 9$ & $11 \cdot 2$ & $0 \cdot 13$ & 0.08 & 0.09 \\
\hline
\end{tabular}

ND, Not detectable $(<0.1 \mathrm{~mm})$.

\section{RESULTS}

Intracellular free amino acid pool

The concentration of amino acids in the intracellular pool extracted from B. amylophilus in the early-stationary phase of growth in batch cultures was 6 to $15 \mathrm{~mm}$. This is similar to the range reported for other Gram-negative bacteria by Brown \& Stanley (1972) and considerably smaller than the range in Gram-positive bacteria (Tempest et al., 1970). However, the size $(15 \mathrm{~mm})$ and the proportion of glutamate $(7 \%)$ in the intracellular pool after growth was limited by the availability of maltose were different from the size $(6 \mathrm{~mm})$ and the proportion of glutamate $(22 \%)$ after ammonia-limited growth. The pool size varied with the population density; the concentration of the growth-limiting nutrient was therefore adjusted so that a similar bacterial density was obtained in each case.

Tempest et al. (1970) reported that the nature of the growth-limiting nutrient had little influence on the total intracellular free amino acid concentration in Aerobacter aerogenes during growth in chemostat cultures in which the environment was strictly regulated. It was possible that the pool size was much lower at peak growth in ammonia-limited batch cultures of $B$. amylophilus because, under these conditions, lysis was rapid. However, the pool extracted from $B$. amylophilus growing under ammonia limitation in chemostat culture was always smaller than that from bacteria growing under maltose limitation at the same dilution rate (Table 1 ). The effect of increasing $D$ was, nevertheless, to effect an 
Table 2. Influence of dilution rate and nature of nutrient limitation on the specific activity of glutamate dehydrogenase (GDH), glutamine synthetase $(G S)$, malate dehydrogenase $(M D H)$, glutamate-oxaloacetate transaminase (GOT) and glutamate-pyruvate transaminase (GPT) during growth of $B$. amylophilus in chemostat cultures

Bacterial extracts were prepared with a Hughes pressure cell. Specific enzyme activities are expressed as nmol product formed $\mathrm{min}^{-1}(\mathrm{mg} \text { protein })^{-1}$. Ammonia-limited cultures washed out at $D>0.29 \mathrm{~h}^{-1}$.

Nutrient
limitation
Ammonia
Ammonia
Ammonia
Ammonia
Ammonia
Maltose
Maltose
Maltose
Maltose

Nutrient

Ammonia

Ammonia

Ammonia

Maltose

Maltose
Specific enzyme activity

$\begin{array}{cccccc}\begin{array}{c}\text { Dilution } \\ \text { rate }\left(\mathrm{h}^{-1}\right)\end{array} & \text { GDH } & \text { GS } & \text { MDH } & \text { GOT } & \text { GPT } \\ 0 \cdot 043 & 747 & \text { NM } & \text { NM } & \text { NM } & \text { NM } \\ 0 \cdot 080 & 760 & 113 & \text { NM } & 139 & 69 \\ 0 \cdot 120 & 725 & 133 & \text { NM } & 83 & \text { NM } \\ 0 \cdot 150 & 633 & 138 & 3707 & 254 & \text { NM } \\ 0 \cdot 204 & 691 & \text { NM } & \text { NM } & 159 & 58 \\ 0 \cdot 033 & 1575 & 62 & \text { NM } & \text { NM } & - \\ 0 \cdot 080 & 1973 & 37 & \text { NM } & 140 & \text { NM } \\ 0 \cdot 150 & 2840 & 10 & 2919 & 182 & 22 \\ 0 \cdot 390 & 2771 & 12 & 3923 & 206 & \text { NM }\end{array}$

NM, Not measured.

increase in pool size. Much of this increase could be attributed to alanine which always predominated.

At $D=0.09 \mathrm{~h}^{-1}$, the concentration of amino acids in the supernatant was about $30 \%$ of that in the intracellular pool during ammonia-limited growth, and about $4 \%$ of that in the pool during maltose-limited growth. The low concentration of intracellular amino acids in ammonia-limited cultures might have been partly due to amino acid excretion and cell lysis. The amino acid composition of the supernatants reflected that of the cell pools so there was no evidence for selective excretion. Furthermore, the amount and composition of the amino acids in the cell pools and culture supernatants were unaffected when the cysteine in the culture medium was replaced by ascorbate $\left(0.5 \mathrm{~g} \mathrm{l}^{-1}\right)$ and $\mathrm{Na}_{2} \mathrm{~S} .9 \mathrm{H}_{2} \mathrm{O}$ $\left(0 \cdot 2 \mathrm{~g} \mathrm{I}^{-1}\right)$.

\section{Specific enzyme activities}

The activities of GDH, GOGAT, GS, MDH, ADH, GOT and GPT were measured with bacterial extracts prepared with a Hughes pressure cell from organisms growing under maltose or ammonia limitation in a chemostat (Table 2). There was an inverse relationship between the specific activities of GDH and GS, and a low concentration of ammonia (about $0.1 \mathrm{~mm}$ ) promoted an increase in specific GS activity. The specific activities of MDH, GOT and GPT did not vary significantly with $D$ or with the nature of the growthlimiting nutrient, although specific GPT activity was often lower when maltose limited growth. Neither GOGAT nor ADH activities were detected even under a wide range of assay conditions.

GHD was $\mathrm{NADP}^{+}$-specific; the activity with $\mathrm{NAD}^{+}$was about $5 \%$ of that with $\mathrm{NADP}^{+}$. The activity of $\mathrm{GDH}$ with $\mathrm{NADP}^{+}$as measured by glutamate oxidation at $\mathrm{pH} 8.0$ was 10 to $15 \%$ of that measured by glutamate formation.

GS activity was measured by the rate of $\gamma$-glutamyl hydroxamate formation; with the biosynthetic reaction (synthetase) the activity was only 5 to $10 \%$ of that of the transferase reaction. The $\gamma \mathrm{GT}$ activity in extracts of $B$. amylophilus was unaffected or occasionally slightly stimulated by the presence of $60 \mathrm{~mm}-\mathrm{Mg}^{2+}$. 


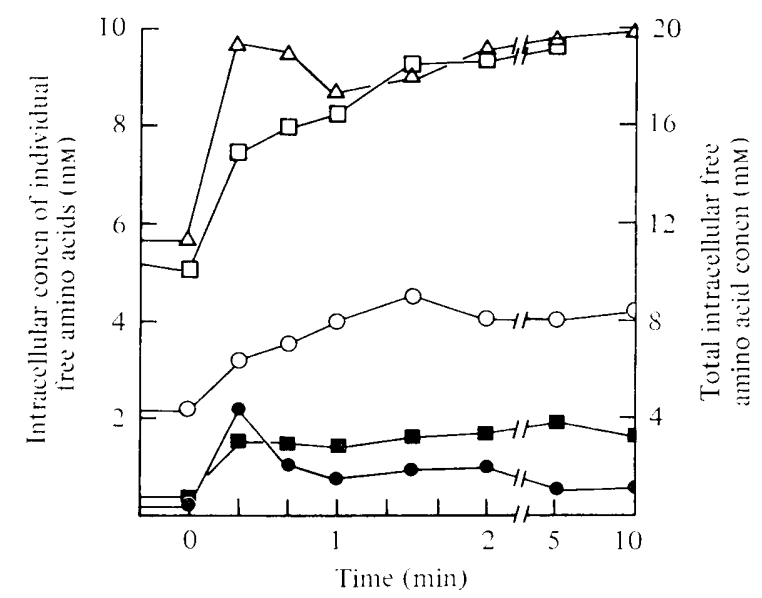

Fig. 1. Changes in the intracellular free amino acid pool content and composition of B. amylophilus following an ammonia 'pulse' to an ammonia-limited chemostat culture $\left(D=0 \cdot 15 \mathrm{~h}^{-1}\right)$. At time zero, the ammonia concentration in the culture was increased from $<0.1 \mathrm{~mm}$ to approx. $7 \mathrm{~mm}$ by the rapid addition of sterile ammonium sulphate solution. Bacteria were harvested by filtration and their free amino acid content was assessed as described in Methods: $\bigcirc$, glutamate; $\bullet$ glutamine; $\square$, alanine; $\boldsymbol{\square}$, valine; $\triangle$, total pool.

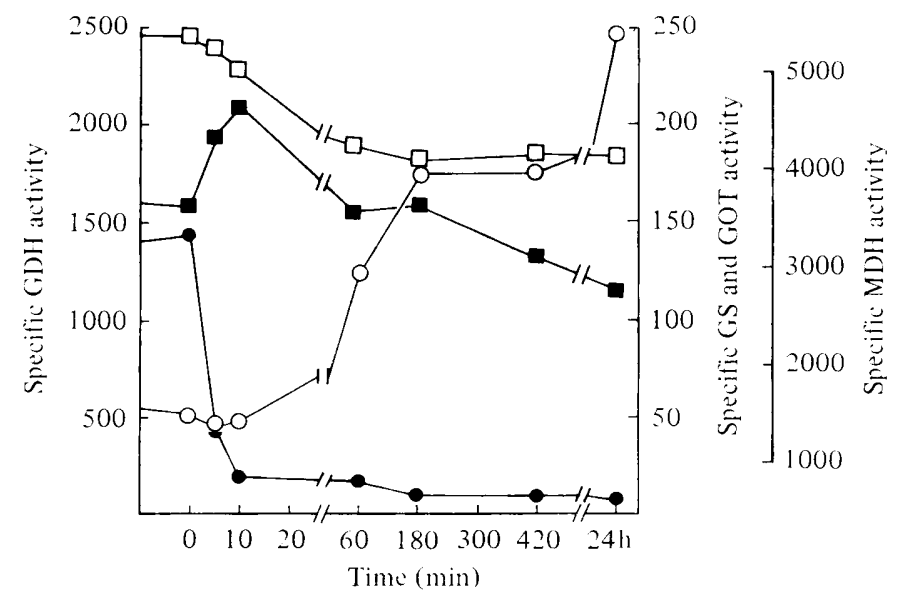

Fig. 2. Changes in the specific activities of some enzymes in B. amylophilus following an ammonia 'pulse' to an ammonia-limited chemostat culture $\left(D=0 \cdot 15 \mathrm{~h}^{-1}\right)$. At time zero, the ammonia concentration in the culture was increased from $<0.1 \mathrm{~mm}$ to approx. $7 \mathrm{~mm}$ by the rapid addition of sterile ammonium sulphate solution. About $1 \mathrm{~h}$ after the pulse, the medium entering the growth vessel was changed to one which led to maltose-limited growth. Bacteria were harvested by centrifugation at $4{ }^{\circ} \mathrm{C}$, resuspended in buffer and ultrasonically disrupted as described in Methods. Enzyme specific activity is expressed as nmol product formed $\min ^{-1}(\text { mg protein })^{-1}: 0$, glutamate dehydrogenase $(\mathrm{GDH})$; $\bigcirc$, glutamine synthetase (GS); $\square$, glutamate-oxaloacetate transaminase (GOT); $\mathbf{\square}$, malate dehydrogenase (MDH).

\section{Routes of ammonia assimilation}

To investigate further the routes by which ammonia might be assimilated, ammonia was pulsed into an ammonia-limited chemostat culture $\left(D=0.15 \mathrm{~h}^{-1}\right)$ and the subsequent changes in amino acid pool content and specific activities of GDH, GS, MDH and GOT were recorded. About $1 \mathrm{~h}$ after the pulse, the medium entering the growth vessel was changed to one which led to maltose limited growth.

The pulse of excess ammonia (final concn $7 \mathrm{~mm}$ ) effected a 10-fold increase in the pool 
concentration of glutamine within $20 \mathrm{~s}$ which decayed to less than half the peak value by $40 \mathrm{~s}$ (Fig. 1). There was also a threefold increase in the valine concentration after $40 \mathrm{~s}$ and and a twofold increase in the glutamate concentration over a period of $90 \mathrm{~s}$. The high activity of GDH in extracts at all times indicated that when ammonia was available glutamate could be synthesized rapidly. The increases in alanine and valine might be due to their ease of formation from the intermediary metabolites, such as pyruvate, formed during maltose breakdown. The possibility that alanine was formed from glutamine by a reaction analagous to that catalysed by GOGAT was investigated, but no activity could be demonstrated.

The specific GS activity ( $\gamma \mathrm{GT}$ ) decreased to about $30 \%$ of the initial value within 5 min (Fig. 2) while the specific GDH activity increased fivefold over a $24 \mathrm{~h}$ period. By this time the culture was maltose-limited and the GS activity was very low.

\section{Effect of $\mathrm{pH}, \mathrm{NaCl}$, cations and amino acids on $\mathrm{GDH}$ activity}

The $\mathrm{pH}$ for optimum GDH activity was $8 \cdot 2$ to $8 \cdot 3$. At $\mathrm{pH} 6 \cdot 5$ the activity was $40 \%$ of the optimum, and at $\mathrm{pH} 9 \cdot 5$ the activity was negligible. Activity was stimulated twofold by $50 \mathrm{~mm}-\mathrm{NaCl}$ or $-\mathrm{KCl}$ and reached a maximum (about 2.5 fold stimulation) at $100 \mathrm{~mm}-\mathrm{NaCl}$; the same effects were observed with Tris/ $\mathrm{HCl}$ at 100 and $150 \mathrm{mM}$. Activity was relatively unaffected by the addition of $100 \mathrm{~mm}$-aspartate or -alanine but $50 \mathrm{~mm}$-glutamate gave $35 \%$ inhibition.

\section{Michaelis constant for ammonia of $G D H$}

From Lineweaver-Burk plots, the $K_{\mathrm{m}}$ value for ammonia of GDH at optimum $\mathrm{pH}$ was $1.7 \mathrm{~mm}$ with $50 \mathrm{~mm}$-Tris/ $\mathrm{HCl}$ buffer in the reaction mixture, $2.1 \mathrm{~mm}$ with $50 \mathrm{~mm}-\mathrm{KH}_{2} \mathrm{PO}_{4} /$ $\mathrm{KOH}$ buffer, and $1.0 \mathrm{~mm}$ at $\mathrm{pH} 7.6$ with $150 \mathrm{~mm}-\mathrm{Tris} / \mathrm{HCl}$ buffer.

\section{DISCUSSION}

The amino acid pool content of Bacteroides amylophilus differed from that of some other bacteria (Tempest et al., 1970; Brown \& Stanley, 1972) in that it was markedly influenced by the environmental ammonia concentration. The decrease in pool content under ammonia limitation may have been due to some extent to cell lysis which was evident under these conditions (since pool concentrations were expressed in $\mathrm{mM}$ on the basis of bacterial dry weight measurements) or to amino acid leakage (Henderson et al., 1969). Both of these factors might have accounted for some of the amino acids in the ammonia-limited culture supernatants, but the extent of protein breakdown, which could account for a major part of these amino acids, was not investigated.

The present results do not allow any firm conclusions to be drawn as to the role that any one pool amino acid might play in the physiology of growth of this organism. However, the rather broad $\mathrm{pH}$-activity profile of GDH might not be consistent with the mechanism of osmoregulation proposed by Brown \& Stanley (1972) in which glutamate may function. The predominance of alanine under all growth conditions was probably not due to the fixation of ammonia through pyruvate because no ADH activity was detected. A transamination through glutamate seemed unlikely to account for the high alanine content of the pool because GPT was also inactive. If, however, a large proportion of the alanine arose from a transamination of pyruvate with aspartate, then this might explain the high activities of GOT and MDH. This scheme would also suggest a direct involvement of $\mathrm{CO}_{2}$ in amino acid biosynthesis (see Caldwell et al., 1969).

The amount of GS in many bacteria is dependent upon the nitrogen source and this enzyme may be essential for nitrogen assimilation when the available nitrogen is present at very low concentrations (Magasanik et al., 1974). The results presented would indicate that in B. amylophilus, GDH functions to assimilate ammonia when the availability is high 
$(>1 \mathrm{~mm}$ ) and GS is repressed. The specific activity of GDH may have increased concomitantly with growth rate under these conditions so that the nitrogen requirement for the increased rate of protein synthesis was met. When the concentration of ammonia is low $(<0.5 \mathrm{~mm})$ and the intracellular free amino acid concentration is depressed, GS is derepressed. Assimilation of ammonia may then proceed with the formation of glutamine. However, the absence of GOGAT would require that glutamate be provided for glutamine synthesis by some other reaction. In view of the relatively low $K_{\mathrm{m}}$ of the GDH for ammonia compared, for example, with that of Escherichia coli (Umbarger, 1969), the activity of GDH in extracts of $B$. amylophilus growing at $D=0.15 \mathrm{~h}^{-1}$ in $0.1 \mathrm{~mm}$-ammonia would be sufficient to provide glutamate at a rate in excess of that required for glutamine synthesis in vivo. However, this assumes that enzyme activities are similar in vitro and in vivo.

It is difficult to assess the significance of the inactivation of GS. It was probably not due to adenylation because the state of adenylation had little effect on the $\gamma$ GT activity of the E. coli enzyme (Wohlhueter et al., 1973). Under slightly modified assay conditions, $\mathbf{M n}^{2+}$ supports the $\gamma \mathrm{GT}$ activity of both the adenylated (biosynthetically inactive) and the unadenylated (active) E. coli enzyme, but in the presence of $60 \mathrm{~mm}-\mathrm{Mg}^{2+}$ only the unadenylated enzyme is active (Shapiro \& Stadtman, 1970 b). Since $\mathrm{Mg}^{2+}$ had little effect on the $\gamma \mathrm{GT}$ activity of the $B$. amylophilus enzyme, this might suggest that an adenylation type mechanism did not operate. However, the $\gamma \mathrm{GT}$ activities of GS enzymes from different sources vary markedly in their responses to $\mathrm{Mg}^{2+}$ (Bender et al., 1977; Nyberg \& Clarke, 1978).

The present results and those of Pulman \& Johnson (1978) indicate that the possession of GOGAT may not be as widespread amongst the prokaryotes as was first thought (see Tyler, 1978). Since B. amylophilus survives and grows in the rumen despite the lack of GOGAT and the evident inability to fix gaseous nitrogen (Jones \& Thomas, 1974), the concentration of ammonia in the rumen is likely to be adequate.

Part of this work was presented in a Ph.D. thesis to the University of Nottingham by H.F.J., who gratefully acknowledges receipt of a postgraduate studentship from the Ministry of Agriculture, Fisheries and Food. The authors thank Mr D. Bozon for technical assistance with the amino acid analyses.

\section{REFERENCES}

Allison, M, J. (1970). Nitrogen metabolism of ruminal micro-organisms. In Physiology of Digestion and Metabolism in the Ruminant, pp. 456-473. Edited by A. T. Phillipson. Newcastle-upon-Tyne: Oriel Press.

Atkin, G. E. \& Ferdinand, W. (1970). Accelerated amino acid analysis. Studies on the use of lithium citrate buffers and the effect of n-propanol in the analysis of physiological fluids and protein hydrolysates. Analytical Biochemistry 38, 313329.

Bender, R. A., Janssen, K. A., Resnik, A. D., Blumenberg, M., Foor, F. \& MagasaniK, B. (1977). Biochemical parameters of glutamine synthetase from Klebsiella aerogenes. Journal of Bacteriology 129, 1001-1009.

Blackburn, T. H. (1965). Protease Production by Bacteroides amylophilus, a Rumen Bacterium. Ph.D. thesis, University of Aberdeen.

Blackburn, T. H. (1968). Protease production by Bacteroides amylophilus strain $\mathrm{H}-18$. Journal of General Microbiology 53, 27-36.

Brown, C. M. \& Stanley, S. O. (1972). Environment mediated changes in the cellular content of the 'pool' constituents and their associated changes in cell physiology. In Environmental Control of Cell Synthesis and Function, pp. 363389. Edited by A. C. R. Dean, S. J. Pirt \& D. W. Tempest. London: Academic Press.

Brown, C. M., Macdonald-Brown, D. S. \& MeErs, J. L. (1974). Physiological aspects of microbial inorganic nitrogen metabolism. $A d$ vances in Microbial Physiology 11, 1-52.

Buttery, P. J. \& Annison, E. F. (1973). Considerations of the efficiency of amino acid and protein metabolism in animals. In The Biological Efficiency of Protein Production, part III, pp. 145-171. Edited by J. G. W. Jones. Cambridge: Cambridge University Press.

Caldwell, D. R., Keeney, M. \& Van Soest, P. J. (1969). Effects of $\mathrm{CO}_{2}$ on growth and maltose fermentation by Bacteroides amylophilus. Journal of Bacteriology 98, 668-676.

Chalupa, W., Clark, J., Opliger, P. \& Lavker, R. (1970). Ammonia metabolism in rumen bacteria and mucosa from sheep fed soy protein or urea. Journal of Nutrition 100, 161-169.

Cole, J. A., Coleman, K. J., Compton, B. E., 
Kavanagh, B. M. \& Keevil, C. W, (1974). Nitrite and ammonia assimilation by anaerobic continuous cultures of Escherichia coli. Journal of General Microbiology 85, 11-22.

Conway, E. J. (1962). Microdiffusion Analysis and Volumetric Error, 5th edn. London: Crosby Lockwood \& Son.

DaInTy, R. H (1972). Glutamate biosynthesis in Clostridium pasteurianum and its significance in nitrogen metabolism. Biochemical Journal 126, 1055-1056.

Dawson, P. S. S. (1965). The intracellular amino acid pool of Candida utilis during growth in batch and continuous flow culture. Biochimica et biophysica acta 111, 51-56.

Dubois, M., Gilles, K. A., Hamilton, J. K., Rebers, P. A. \& SMITH, F. (1956). Colorimetric method for determination of sugars and related substances. Analytical Chemistry 28, 350-356.

Griffith, C. J. \& Carlsson, J. (1974). Mechanism of ammonia assimilation in streptococci. Journal of General Microbiology 82, 253-260.

Henderson, C., Hobson, P. N. \& Summers, R. (1969). The production of amylase, protease and lipolytic enzymes by two species of anaerobic rumen bacteria. In Continuous Cultivation of Micro-organisms, pp. 189-204. Edited by I. Malek. Prague: Academia.

Hobson, P. N. (1965). Continuous culture of rumen bacteria: apparatus. Journal of General Microbiology 38, 161-166.

Hobson, P. N. \& Summers, R. (1967). The continuous culture of anaerobic bacteria. Journal of General Microbiology 47, 53-65.

HuGHES, D. E. (1951). A press for disrupting bacteria and other micro-organisms. British Journal of Experimental Pathology 32, 97-109.

Hullah, W. A. \& Blackburn, T. H. (1971). Uptake and incorporation of amino acids and peptides by Bacteroides amylophilus. Applied Microbiology 21, 187-191.

Hungate, R. E. (1966). The Rumen and Its Microbes. London: Academic Press.

JoNes, K. \& ThOMAS, J. G. (1974). Nitrogen fixation by the rumen contents of sheep. Journal of General Microbiology 85, 97-101.

JoYNer, A. E., JR \& BALdwin, R. L. (1966). Enzymatic studies of pure cultures of rumen microorganisms. Journal of Bacteriology 92, 1321-1330.

Latham, M. J. \& Sharpe, E. M. (1971). The isolation of anaerobic organisms from the bovine rumen. In Isolation of Anaerobes, pp. 132-147. Edited by D. A. Shapton \& R. G. Board. London: Academic Press.

LEWIS, D. \& SwaN, H. (1971). The role of intestinal flora in animal nutrition. Symposia of the Society for General Microbiology 21, 149-175.
Magasanik, B., Prival, M. J., Brenchley, J. E., Tyler, B. M., Deleo, A. M., Streicher, S. L., Bender, R. A. \& Paris, C. G. (1974). Glutamine synthetase as a regulator of enzyme synthesis. Current Topics in Cellular Regulation 8, 119-138.

Meers, J. L., Tempest, D. W. \& Brown, C. M. (1970). 'Glutamine(amide): 2-oxoglutarate amino transferase oxido-reductase (NADP)', an enzyme involved in the synthesis of glutamate by some bacteria. Journal of General Microbiology 64, 187-194.

NybERG, K. \& Clark, P. H. (1978). Glutamine synthetase activities of cultures of Pseudomonas aeruginosa grown in minimal media with histidine, nitrate or ammonium sulphate as the nitrogen source. Journal of General Microbiology 107, 193197.

Pulman, D. \& Johnson, B. (1978). The enzymes of ammonia assimilation and their control in members of the genus Erwinia. Journal of General Microbiology 106, 137-143.

Reeves, H. C., Rabin, R., Wegener, W. S. \& AJl, S. J. (1971). Assays of enzymes of the tricarboxylic acid and glyoxylate cycles. Methods in Microbiology 6A, 425-462.

Rowe, W. B., Ronzio, R. A., Wellner, V. P. \& Meister, A. (1970). Glutamine synthetase (sheep brain). Methods in Enzymology 17A, 900-910.

Shapiro, B. M. \& Stadtman, E. R. $(1970 a)$. The regulation of glutamine synthesis in microorganisms. Annual Review of Microbiology 24, 501-524.

Shapiro, B. M. \& Stadtman, E. R. (1970b). Glutamine synthetase (E. coli). Methods in Enzymology 17A, 910-922.

Tempest, D. W., Meers, J. L. \& Brown, C. M. (1970). Influence of environment on content and composition of microbial free amino acid pools. Journal of General Microbiology 64, 171-185.

TYLER, B. (1978). Regulation of the assimilation of nitrogen compounds. Annual Review of Biochemistry 47, 1127-1162.

UMBARGER, H. E. (1969). The regulation of amino acid metabolism. Annual Review of Biochemistry 38, 323-370.

Wohlhueter, R. M., Schutt, H. \& Holzer, H. (1973). Regulation of glutamine synthetase in vivo in Escherichia coli. In The Enzymes of Glutamine Metabolism, pp. 45-64. Edited by S. Prusiner \& E. R. Stadtman. New York: Academic Press.

Woolfolk, C. A., Shapiro, B. \& Stadtman, E. R. (1966). Regulation of glutamine synthetase. I. Purification and properties of glutamine synthetase from Escherichia coli. Archives of Biochemistry and Biophysics 116, 177-192. 